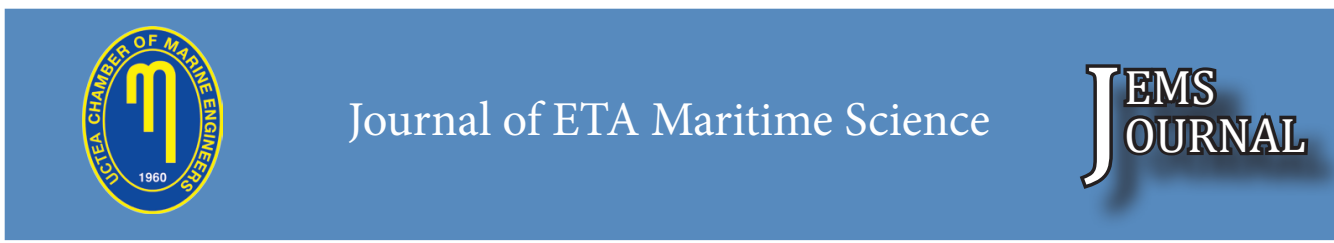

Corresponding Author: Levent BİLGİLI

\title{
The Social Cost and Environmental Life Cycle Analysis of Passenger Ships in Istanbul
}

\section{Levent BILGILII}

Bandırma Onyedi Eylül University, Maritime Faculty, Turkey

lbilgili@bandirma.edu.tr; ORCID ID: https://orcid.org/0000-0001-9431-5289

\begin{abstract}
Calculating the inventory of shipping emissions is crucial in order to guide the authorities to prepare regulations on emission reduction. On the other hand, the effectiveness of the measurement techniques can only be accurately observed by the calculation of social costs. In this study, firstly, the emission inventory and social cost of passenger ships operating in Bosphorus are calculated. Then, these calculations were repeated in case of declaration of the Marmara Sea as Emission Control Area (ECA). The total amount of emissions in current situation decreases by $7.75 \%$ in case of ECA declaration. The total cost of fuel switching increases approximately $39.52 \%$; however the total social cost decreases by $50.56 \%$. The total economic benefit is calculated as $\$ 117,739,686.97$. According to the LCA results, fuel switching increases the deleterious impacts on human health, ecosystem quality and climate change, while the impacts on raw resources decreased.

Keywords: Ship Emissions, Social Cost, Life Cycle Assessment.
\end{abstract}

\section{İstanbul'daki Yolcu Gemilerinin Sosyal Maliyet ve Çevresel Yaşam Döngüsü Analizi}

Öz

Gemi emisyon envanterinin hesaplanmasl, emisyon azaltımı için gerekli düzenlemelerin yapılması için ilgili otoritelere kılavuzluk etmesi açısından çok önemlidir. Öte yandan, emisyonların etkilerinin kesin bir șekilde bilinmesi, bu emisyonların sosyal maliyetlerinin de hesabıyla mümkündür. Bu çalıșmada ilk olarak İstanbul Boğazı'nda faaliyet gösteren yolcu gemilerinin emisyon envanteri ve bu emisyonların sosyal maliyetleri hesaplanmıştır. Ardından, bu hesaplamalar Marmara Denizi'nin Emisyon Kontrol Alanı (ECA) olarak ilan edilmesi durumu için tekrarlanmıştır. Bölgenin ECA olarak ilan edilmesi durumunda emisyonların mevcut duruma göre \% 7,75 azaldığı görülmüștür. Yakıt değiş̧imi nedeniyle toplam yakıt maliyeti \% 39,52 oranında artmıs, toplam sosyal maliyet ise \% 50,56 oranında azalmıștır. Toplam ekonomik kazanç 117.739.686,97 \$ olarak hesaplanmıștır. YDA sonuçlarına göre de yakıt değişimi, insan sağlı̆̆ına, ekosistem kalitesine ve iklim değişikliğine olan zararlı etkileri artırırken ham kaynaklar üzerindeki zararlı etkileri azaltmıștır.

Anahtar Kelimeler: Gemi Emisyonları, Sosyal Maliyet, Yaşam Döngüsü Analizi. 


\section{Introduction}

Parametric roll is uIt is estimated that there are approximately 450 different ship exhaust-gas emissions [1]; however, only a small proportion of these emissions are considered to be a threat to human health and the environment, and some are taken into account because they are produced in large quantities even if they are environmentally harmless. The most environmentally significant components of ship emissions are carbon dioxide ( $\mathrm{CO} 2$ ), sulphur dioxide (SO2), carbon monoxide (CO), hydrocarbons (HC), particulate matter (PM) and nitrogen oxides (NOx).

Ship-related $\mathrm{CO} 2, \mathrm{NOx}$ and sulphur oxides (SOx) emissions, caused by international shipping, account for $2.6 \%$, $15 \%$ and $6.5 \%$ of the total global emissions [2-4]. Although the percentage of these emissions have a little ratio comparing the world's total emission production, [5] stated that $70 \%$ of the ships' emissions occurred at a distance of $400 \mathrm{~km}$ to the shore.

In this study, firstly, emission estimations for the ferries operating in Istanbul were calculated. Then, the economic, social and environmental results were analysed in case of declaration of the Marmara Sea as ECA.

\section{Literature Review}

A great number of comprehensive studies have been carried out over the last two decades, in particular on the formation, dispersion and environmental impacts of ship emissions. [6] conducted one of the first studies on the global ship emission inventory and focused mainly on NOx and SOx emissions. Based on the data of 1993, the amount of global NOx and SOx emissions from ship emissions was calculated as 3.08 and $4.24 \mathrm{Tg}$, respectively. [4], have recalculated global ship emissions based on engine power in their updated study and concluded that the amount of ship-related
NOx emissions is $6.87 \mathrm{Tg}$. [7] calculated global ship-related emissions between 1925 and 2002 and found that ship-related SO2 and CO2 emissions increased by 3.4 and 2.8 times, respectively. [8, 9] reported that ship-related SO2 emissions in the Asian seas accounted for $0.7 \%$ of the total SO2 emissions in the Asian continent and SO2 amount increased by $5.9 \%$ in 1988-1995. [10] calculated ship-related emissions in the Bosphorus and the Dardanelles and found that total emissions in these two regions are 700,386 t. [11] have calculated that the amount of ship-related emissions is $5,680,275 \mathrm{t}$ in the Marmara Sea as of 2003. According to the study conducted by [12], the amount of ship-related emissions in Ambarlı Port of Istanbul is 82,344 tons. [13] calculated the total ship-related emissions in the Gibraltar Strait for the year 2007 and the amount is $1,447,171.77$ t. [14] have studied on four Portuguese ports and found that ship-related emissions increased by an average of $20 \%$ between 1990 and 2014 . [15] have studied on four different ports in different regions of the world and they have found that the total greenhouse gas (GHG) production is $582,000 \mathrm{t}$ as $\mathrm{CO} 2$ equivalent.

Besides global and regional studies, International Maritime Organization (IMO) published three significant and comprehensive studies on ship-related emissions. [16] calculated the total shiprelated emissions by obtaining the total fuel consumption and investigated the geographic dispersion of these emissions. [17] included the abatement technologies, the future projections of ship-related emissions and the comparative assessment of ship-related $\mathrm{CO} 2$ emission with other transportation modes. [2] is the last and the most current publication and it roughly consists of the calculation of ship-related flue gas emissions for 2007-2012 and the future projections for 2012-2050. In addition, IMO has developed emission factors in all three studies. 
In the past two decades, generally conventional estimation methods have been used to calculate ship-related emissions; however, the emissions are strongly depend on the ship motion and some other dynamic variables. Thus, innovative estimation methods are needed to achieve more accurate results. One of the first studies, which is based upon Automatic Identification System (AIS) data, was developed by [18]. The authors named the developed systems as Ship Traffic Emissions Assessment Model (STEAM) and it can calculate the ship-related emissions by using ship speed, engine load, fuel sulphur content, abatement technologies and wave effect. [19] used ship speed, engine revolution per minute (RPM), mean draft, trim, cargo amount, wind effect and sea effect as inputs in order to calculate fuel consumption. The authors developed an Artificial Neural Network (ANN). [20] developed some formulas by using nine bulk carriers' noon reports in order to estimate ship-related emissions as a function of deadweight (DWT) and block coefficient (CB). [21] developed an ANN methodology to calculate ship-related emissions as a function of voyage duration, engine RPM, ship speed, displacement, weather condition, sea condition and mean draft. It was found out that the difference between the real and estimated data is 1.57 $\%$. The author has also concluded that there is a strong correlation between weather and sea conditions and emission amounts.

Additionally, some studies have focused on the geographic dispersion of ship-related emissions. [22] used satellite images and found that ship-related nitrogen dioxide (NO2) emissions were concentrated in the Persian Gulf, the Malacca Strait and the North China Sea. In a similar study, [23] found that NO2 emissions increased by $86 \%$ from 2003 to 2008 and decreased by $24 \%$ in 2008-2009 due to slowing ship traffic because of the global crisis.
[24] studied on global dispersion of shiprelated CO2 emissions for 2015. According to the results, container vessels are mostly concentrated in East Asia, tankers in East Asia and the Arabian Peninsula, cruise ships in the Caribbean region and fishing vessels in the North Atlantic.

Although the estimation of ship emissions by conventional or innovative methods, emission inventory preparation and geographical distribution of ship emissions provides very useful information on the control of these emissions, the financial statements generated by shiprelated emissions should be examined separately and in detail. Social costs of the emissions includes the impacts of emissions to the human health and the environment. [25] describes the social cost as "changes in net agricultural productivity, human health, property damages from increased flood risk and the value of ecosystem services". [26] calculated that the amount of ship emissions from ship operations in some ports of Greece is $2742.7 \mathrm{t}$ and emissions yielded a cost of $€ 18$ million to public health. [27] concluded a similar study for the Port of Bergen in Norway and concluded that ship emissions accounted for around $€ 16$ million. [28] examined the Shanghai Port of China, and the total amount of emissions in the port is $598,460 \mathrm{t}$, while the total cost of the emissions calculated as $\$ 286,748,496$ million. [29] conducted studies for the port of Kotor (Montenegro) and Dubrovnik (Croatian), and found that ship emissions for the Port of Dubrovnik and Kotor were \$ 7.9 and \$ 3.6 million, respectively. [30] conducted a study on Piraeus Port of Athens, Greece and it was found that the external costs of shipping emissions is approximately $€ 51$ million, annually. [31] calculated the economic cost of NOx and SO2 in the United States for 1993-2001. The results show that the externalities for NOx and SO2 are \$ 256 and \$ 412 million, annually and respectively. [32] examined 
the externalities of shipping emissions in the Gulf of Finland. The authors estimated that the average externalities except $\mathrm{CO} 2$ is approximately $\$ 52,143,709$ for 2007 2015. [33] indicated that total externalities of Greek shipping emissions reached $€$ 3.1 billion and this value corresponds 1.7 $\%, 6.8 \%$ and $28.8 \%$ of the costs incurred globally, within the European seas and the Mediterranean, respectively. [34] have also investigated the total external costs of shipping for different pollutant categories such as marine pollution, air quality and GHG's.

\section{Regulations on Reducing Ship-Related Emissions}

While environmental, economic and health risks of ship emissions are a major problem today, it is obvious that in case of not taking adequate measures, more serious problems will be faced in the future. Important steps have been taken to control ship emissions through international and national studies.

[35] realized a future projection based upon the Special Report on Emission Scenarios (SRES), which was prepared by Intergovernmental Panel for Climate Change (IPCC), and estimated that the total fuel consumption of ships will increase from 280 t to $536 \mathrm{t}$, at least. In addition, Table 1 presents the future projections of IMO for different emissions.

As it can be seen in Table 1, the general

Table 1. IMO Projections for Different Pollutant Types [2]

\begin{tabular}{|c|c|c|c|}
\hline $\begin{array}{l}\text { Pollutant } \\
\text { Types }\end{array}$ & $\begin{array}{l}2012 \text { Index } \\
(2012=100)\end{array}$ & $\begin{array}{l}2020 \text { Index } \\
(2012=100)\end{array}$ & $\begin{array}{l}2050 \text { Index } \\
(2012=100)\end{array}$ \\
\hline $\mathrm{CO}_{2}$ & 100 & 107 & 178 \\
\hline $\mathrm{NO}_{\mathrm{x}}$ & 100 & 103 & 146 \\
\hline $\mathrm{SO}_{\mathrm{x}}$ & 100 & 60 & 25 \\
\hline PM & 100 & 71 & 70 \\
\hline $\mathrm{CO}$ & 100 & 118 & 226 \\
\hline
\end{tabular}

trend of the emissions is to increase by years. CO2, NOx and $\mathrm{CO}$ emissions are estimated to increase by $78 \%, 46 \%$ and $126 \%$, respectively in 2050 according to the base value of 2012 . On the other hand, it is estimated that SOx and PM emissions are estimated to decrease by $75 \%$ and $30 \%$ in the same period. It is because of Emission Control Areas (ECA).

ECA's are identified by IMO based upon Regulation 13 (NOx) and 14 (SOx and PM) of International Convention for the Prevention of Pollution from Ships (MARPOL) Annex VI. ECA's are special sea areas in which stricter regulations are in force especially on sulphur content of marine fuels. While current sulphur content limit is $3.5 \%$ mass for other sea areas, the current limit for ECA is $0.1 \%$ mass. While the West and East Coasts of United States and Canada and the coasts of Hawaii are identified ECA for both Regulation 13 and Regulation 14, the Baltic Sea and the North Sea areas are identified as ECA for only Regulation 14. Besides, Regulation 12, Regulation 15, Regulation 16 and Regulation 18 of MARPOL Annex VI are about ozone depleting substances, volatile organic compounds, shipboard incineration and fuel oil availability and quality, respectively. The NOx limitations indicated in Regulation 13 are presented in Table 2.

The first studies of European Commission (EC), which was prepared on the sulphur content of certain liquid fuels, was published in 1993 with the name of Directive 93/12/EEC. This directive was completely about Greek fleet and it is briefly mentioned that Greek fleet must obey the rules which are determined by the port state. Directive 1999/32/EC brought some new rules for sulphur content of marine fuels and it was indicated that the regulations of EC must be in unison with MARPOL restrictions. Directive 2005/33/ $\mathrm{EC}$ is the first comprehensive publication of EC on marine fuels. The directive firstly 
Table 2. $\mathrm{NO}_{x}$ Limitations

\begin{tabular}{|l|l|l|}
\hline Tier & NO $_{\mathrm{x}}$ Limit & RPM \\
\hline Tier I (01.01.2001-01.01.2011) & $\begin{array}{l}17 \mathrm{~g} \mathrm{kWh}-1 \\
45 \times \mathrm{x}-0.2 \mathrm{~g} \mathrm{kWh}-1 \\
9.8 \mathrm{~g} \mathrm{kWh}-1\end{array}$ & $\begin{array}{l}\mathrm{n}<130 \\
130<\mathrm{n}<2000 \\
\mathrm{n}>2000\end{array}$ \\
\hline \multirow{3}{*}{ Tier II (After 01.01.2011) } & $\begin{array}{l}14.4 \mathrm{~g} \mathrm{kWh}-1 \\
44 \times \mathrm{n}-0.23 \mathrm{~g} \mathrm{kWh}-1\end{array}$ & $\begin{array}{l}\mathrm{n}<130 \\
130<\mathrm{n}<2000 \\
\mathrm{n}>2000\end{array}$ \\
\hline \multirow{2}{*}{ Tier III (After 01.01.2016) } & $\begin{array}{l}3.4 \mathrm{~g} \mathrm{kWh}-1 \\
9 \times \mathrm{n}-0.2 \mathrm{~g} \mathrm{kWh}-1\end{array}$ & $\begin{array}{l}\mathrm{n}<130 \\
130<\mathrm{n}<2000 \\
\mathrm{n}>2000\end{array}$ \\
\hline
\end{tabular}

identifies the general information and potential threats of marine fuels and explains solution proposals in general. The directive is generally in unison with MARPOL requirements and defines an exception for military vessels. Rules on trial and use of new emission abatement technologies are also determined. Directive 2012/33/EU includes some amendments and additional substances to Directive 1999/32/EC. According to the directive, the sulphur content of ship fuels cannot exceed $0.5 \%$ in the European Economic Zone after 2020. The last study of European Union (EU) on shipping emissions was published with the name of Directive (EU) 2016/802, which includes some new identifications and regulations. It is important to see that EU directives have generally strong bounds with MARPOL and it can be said that EU follows IMO to determine its own regulations [36].

As a result of these preventive rules, [37] stated that the SO2 release in European ports decreased by $66 \%$, but no such reduction was observed in the Tunisian ports which were not subject to any restrictive directive. On the other hand, [38] and [39] stated that the issue of emission reduction could have hidden effects and that the financial dimension of these studies should be well investigated.

\section{Materials and Methods}

In this study, passenger ships, which are actively operated in Bosphorus and Istanbul shores of the Marmara Sea, are investigated for the years 2011-2016. The ships had a total of 9882 trips during the six-year period. The data was obtained from the database of the company. Besides, the fuel consumption of the ships were also obtained from the company.

There are several methods for estimating ship-related airborne emissions. In this study, fuel consumption (FC) method was used. The formula for FC method was offered by [40] and presented below:

$E_{\text {Trip, } \mathrm{ij}, \mathrm{m}}=\sum_{\mathrm{p}}\left(F C_{\mathrm{j}, \mathrm{m} . \mathrm{p}} \mathrm{X} E F_{\mathrm{i}, \mathrm{j}, \mathrm{m}, \mathrm{p}}\right)$

\section{$\mathrm{E}_{\text {Trip }}$ :Total emission ( $\mathrm{t}$ )}

FC :Fuel consumption $(\mathrm{t})$

EF :Emission factor ( $\mathrm{g} / \mathrm{t}$ fuel)

i :Pollutant type

j :Engine type

m :Fuel type

$\mathrm{p} \quad$ :Voyage stages

Emission factors for different pollutants, tiers and different fuel types (Heavy Fuel Oil-HFO and Marine Gas Oil-MGO) are given in Table 3. In the table, the factors of pollutants except NOx are based on the fuel type, while NOx factor also depends on the 
tier, which is identified by IMO according to the built year, of the engine. The emission amounts were calculated by multiplying the emission factors and fuel consumption.

Table 3. Emission Factors ( $t / t$ fuel) [41]

\begin{tabular}{|c|c|c|c|}
\hline Pollutant & Tier & HFO & MGO \\
\hline $\mathrm{CO}_{2}$ & & 3.179 & 3.179 \\
\hline $\mathrm{SO}_{2}$ & & 0.054 & 0.002 \\
\hline $\mathrm{CO}$ & & 0.0051 & 0.0053 \\
\hline $\mathrm{HC}$ & & 0.0009 & 0.001 \\
\hline PM & & 0.00233 & 0.00098 \\
\hline $\mathrm{NO}_{\mathrm{x}}$ & $\begin{array}{l}\text { No Tier } \\
\text { Tier I }\end{array}$ & \begin{tabular}{|l|}
0.0617 \\
0.0498
\end{tabular} & $\begin{array}{l}0.0632 \\
0.0549\end{array}$ \\
\hline
\end{tabular}

The emission factors of $\mathrm{CO} 2$ for both fuels are the same due to the same carbon content of the fuels [41]. The ferries currently use HFO; however, if fuel switching would be mandatory in order to be in accordance with ECA regulations, the ferries should switch their fuels to MGO. Table 4 presents the HFO and MGO average annual prices for 2011-2016 period.

Table 4. HFO and MGO Prices for Years ( $\$ / t$ fuel) [42]

\begin{tabular}{|l|l|l|}
\hline Years & HFO & MGO \\
\hline 2011 & 467.48 & 665.49 \\
\hline 2012 & 606.56 & 915.77 \\
\hline 2013 & 686.00 & 986.06 \\
\hline 2014 & 632.44 & 946.55 \\
\hline 2015 & 614.81 & 920.75 \\
\hline 2016 & 367.55 & 589.53 \\
\hline
\end{tabular}

The social cost of the emissions can be calculated as follows:

$$
\text { Social cost }=\sum_{\mathrm{i}} \text { Emission }_{i} \mathrm{X} \text { Cost Factor }
$$

Table 5 presents the estimated average social costs of ship-related emissions. The average values of cost factors were taken from [28], in which the author utilized a very wide range of previous studies. The average of social costs of previous studies is selected due to the difficulty to decide the most suitable cost factors for different studies. Because there are significant constraints and due to the different conditions for each region, it was determined to use the average values of previous global studies.

Table 5. Social Costs of Pollutants ( $\$ /$ t pollutant)

\begin{tabular}{|l|l|}
\hline Years & Value (\$/t Pollutant) \\
\hline 2011 & 28.5 \\
\hline 2012 & 32,688 \\
\hline 2013 & 1,680 \\
\hline 2014 & 2,287 \\
\hline 2015 & $250,395.5$ \\
\hline 2016 & $29,284.5$ \\
\hline
\end{tabular}

Finally, a Life Cycle Assessment (LCA) were realized for both fuel types to estimate the realistic impacts of utilization of the fuels. The LCA calculations includes the production process of the fuels, mainly. In this study, SimaPro 8.2.3.0 package program, Ecoinvent 3 library and IMPACT 2002+ method were used for LCA calculations. IMPACT 2002+ Developed in 2002 by the Swiss Federal Institute of Technology, it was designed to establish a link between the 14 categories and 4 damage categories. Damage categories are defined as human health, ecosystem quality, climate change and resources. Although the middle categories provide comprehensive information on LCA analysis, there are difficulties in expressing the potential losses in an understandable and simple manner. Damage categories make it possible to understand the damages of products, systems or services to human health and the environment. The LCA calculations processes were based upon the ISO 14040:2006 standards. First, a functional unit was defined in order to determine the restrictions of the system. Then, the Life Cycle Inventory Analysis (LCI) was determined and defined. Finally, 
the Life Cycle Impact Assessment (LCIA) calculations were realized in accordance with the definitions in the standard.

The functional unit used in LCA is fuel in tons. The calculations were restricted with the production of the fuels due to the lack of utilization process in SimaPro program. The LCA was used to calculate the impacts of the total fuel consumption between 2011-2016.

\section{Results and Discussion}

In the first part of the study, the current and projected emission inventory was calculated for the years 2011-2016 via fuel consumption data of the ships and assuming that the ships used HFO. In case of declaration of the Marmara Sea as ECA, the ships will have to use MGO as fuel. The emissions calculated according to the years are presented in Table 6 . the region, there was a significant decrease in SO2 and sulphate (SO4) emissions but nitrate (NO3) emissions increased. [44] also found that the $\mathrm{SO} 2$ emissions in the Rotterdam Port, which is located in the ECA region, were at very low rates as expected. [37] stated that the SO2 reduction in European ports operated in accordance with EC rules is at $66 \%$, but no such reduction has been observed in Tunisia Port, which is not subject to any emission reduction rules.

The declaration of the Marmara Sea as ECA would provide a significant reduction in ship-related emissions; however, as noted by [38] and [39], emission reduction processes have several other effects.

While the current total social costs are \$260.8 million for HFO usage, it would be reduced to $\$ 128.9$ million in case of declaration of ECA. On the other hand,

Table 6. Current and Projected Emission Inventory ( $t$ )

\begin{tabular}{|l|c|c|c|c|c|c|}
\hline CostCase/Pollutant Types & $\mathrm{CO}_{2}$ & $\mathrm{SO}_{2}$ & $\mathrm{CO}$ & $\mathrm{HC}$ & $\mathrm{PM}$ & $\mathrm{NO}_{\mathrm{x}}$ \\
\hline $\begin{array}{l}\text { Current Emissions } \\
(2011-2016)\end{array}$ & $199,372.97$ & $3,386.64$ & 319.85 & 56.44 & 146.13 & $3,659.01$ \\
\hline Projected Emissions & $186,766.25$ & 117.50 & 311.37 & 58.75 & 57.57 & $3,575.43$ \\
\hline
\end{tabular}

It is clearly seen in Table 6 that if the Marmara Sea have been declared as ECA, a significant emission reduction would be observed except for the HC Emissions. Possible reduction rates for $\mathrm{CO} 2, \mathrm{SO} 2, \mathrm{CO}$, $\mathrm{PM}$ and NOx were found as $6.32 \%, 96.53$ $\%, 2.49 \%, 60.6 \%$ and $2.28 \%$, respectively.

[43], in his calculations for the North Sea, stated that after the ECA announcement of while the total cost of HFO was \$ 35.7 million, the total cost for switching to MGO was calculated as $\$ 49.8$ million. Thus, the total benefit of fuel switching due to ECA regulations in the Marmara Sea is estimated as \$ 117.7 million. Figure 1 presents the comparison of social costs in case of fuel switching for different pollutants.

Compared with the previous studies

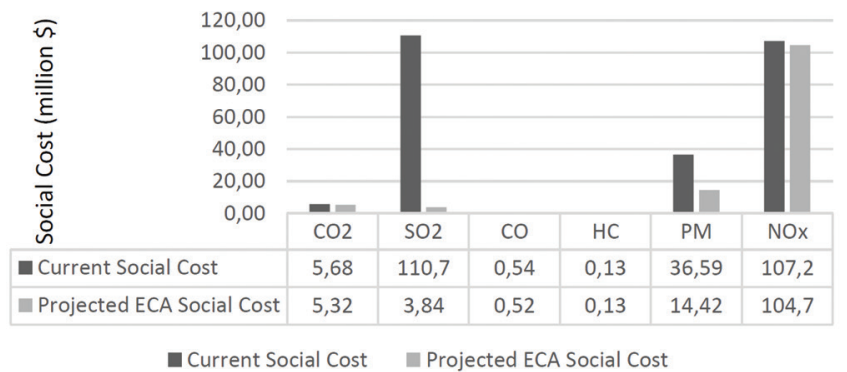

Figure 1. Current and Projected Social Costs (Million \$) 
realized by [26-33], the results show that the social costs of operation of passenger ships could not be underestimated.

The results of the LCA calculations for fuels are given in Figure 2.

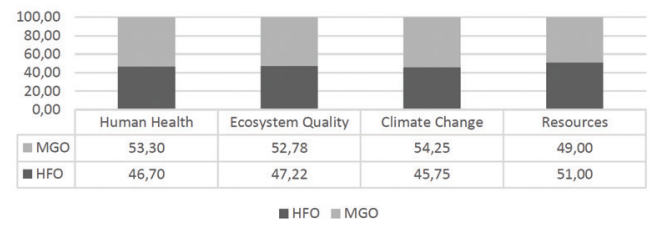

Figure 2. The LCA Results of Fuel Switching

It is seen in Fig. 2 that $53.3 \%$ of the deleterious impacts of the fuels caused by MGO. Similarly, MGO constitutes the $52.78 \%$ and $54.25 \%$ of the harmful impacts of ecosystem quality and climate change, respectively. Only the impacts on the resources are higher for HFO.

Here, DALY is defined as a healthy life lost due to various processes [45]. In DALY calculations, it is assumed that each individual has a healthy life expectancy. This period may decrease over time due to various factors. DALY is an expression of this loss of wellness [46]. The PDF x m ${ }^{2} \mathrm{x}$ yr unit is an expression of the species expected to be lost for 1 year in the $1 \mathrm{~m}^{2}$ piece of earth. $\mathrm{Kg} \mathrm{CO} 2$ eq is a unit in which the effects of various gases are measured in $\mathrm{CO} 2$ in terms of climate change, while $\mathrm{MJ}$ is the expression of the energy consumed when extracting or processing resources [47].

It is observed that although the total emission amounts are decreasing, the negative impacts of fuel switching on human health and climate change are increasing. It is because the consideration of LCA calculations of fuel manufacturing processes. Although only a few types of air emissions have been calculated for emission estimations, many pollutants are emitted to soil, water and air during the processes for the production of each type of fuel. Considering the cumulative effects of all these wastes, it is concluded that the total positive effects of fuel switching is actually limited. Furthermore, even negative effects may occur more.

However, since the social costs of all types of pollutants are impossible to calculate, fuel switching is accepted as a partially successful method. Although it is possible to investigate different types of fuels with more comprehensive LCA models, these calculations are out of focus of this study.

\section{Conclusions}

As one of the largest cities in the world, Istanbul is the centre of a large population movement throughout the day. The unique location of Istanbul, which is considered as an important intersection point of land, sea and air ways, makes the city one of the most dense and especial waterways. Bosphorus, which is a part of Turkish Straits that connects the Black Sea and the Mediterranean, is not only an indispensable waterway for trade ships but also an effective alternative for passengers of Istanbul. Besides, a notable population of Istanbul live in districts which are located near Bosphorus. In this respect, the shipping activities in Bosphorus have importance on social, economic and environmental issues.

In this study, passenger ships that are operating in Bosphorus and the Istanbul shores of the Marmara Sea are investigated and the emission inventory for 2011-2016 is calculated.

Then, the social cost of these emissions is estimated. The estimations are repeated for the potential declaration of the Marmara Sea as ECA.

The obtained results show that ECA declaration increases fuel costs approximately $39.52 \%$; however, the total social costs decrease about $50.56 \%$. It is also calculated that the total benefit for fuel switching is $\$ 117,739,686.97$. In addition, the cumulative effect of fuel change on human health, ecosystem quality and climate change appears to be negative; 
however, the impossibility of social cost calculations for all types of pollutants makes the realistic calculations unfeasible. Therefore, the fuel switching can be used as a partially appropriate emission abatement technique, at least for now.

The fuel and social cost calculated in this study cover passenger ships, which constitute a small part of the total traffic in the Bosphorus, which is a small part of the Turkish Straits System that consists of the Bosphorus and Dardanelles and the Marmara Sea. Besides, these calculations did not cover the direct impacts on human health and some other costs to the environment. Therefore, considering that the total shipping activities are much higher than passenger ship traffic, a holistic approach (in terms of social, environmental, economic and health) to this issue clearly shows that declaration of the Marmara Sea as ECA would provide countless benefits to Turkish and world economy. This study is a guiding first step for a further study which aims to create an emission and social cost inventory for the Marmara Sea and it is planned to be widened and enriched to cover all shipping activities in the Turkish Straits System. In addition, LCA and Life Cycle Cost (LCC) calculations of alternative fuel types for ships are also planned.

\section{Acknowledgements}

SimaPro 8.2.3.0 package program was provided under the sponsorship of Turkish Lloyd.

\section{References}

[1] Andreoni, V., Miola, A., Peujo, A., (2008). Cost effectiveness analysis of the emission abatement in the shipping sector emissions, European Commission Joint Research Centre, Institute for Environment and Sustainability, ISBN: 978-92-79-11280-5, ISSN: 1018-5593.
[2] IMO, 2015. Third IMO Greenhouse Gas Study, Executive Summary and Final Report.

[3] Eyring, V., Köhler, H.W., van Aardenne, J., Lauer, A., (2005). Emission from international shipping: 1 . The last 50 years. Journal of Geophysical Research, 110, D20.

[4] Corbett, J.J. and Köhler, H.W., (2003). Updated emissions from ocean shipping. Journal of Geophysical Research, 108, D20.

[5] Eyring, V., Isaksen, I.S.A. Berntsen, T., Collins, W.J., Corbett, J.J., Endresen, O., Grainger, R.G., Moldanová, J., Schlager, H., Stevenson, D.S., (2010). Transport impacts on atmosphere and climate: Shipping. Atmospheric Environment, 44:4735-4771.

[6] Corbett, J.J., Fischbeck, P.S., Pandis, S.N., (1999). Global nitrogen and sulfur inventories for oceangoing ships. Journal of Geophysical Research, 104, D3:3457-3470.

[7] Endresen, Ø., Sørgård, E., Behrens, H.L., Brett, P.O., Isaksen, I.S.A., (2007). A historical reconstruction of ships' fuel consumption and emissions. Journal of Geophysical Research, 112, D12301.

[8] Streets, D.G., Carmichael, G.R., Arndt, R.L., (1997). Sulfur dioxide emissions and sulfur deposition from international shipping in Asian Waters. Atmospheric Environment, 31(10):1573-1582.

[9] Streets, D.G., Guttikunda, S.K., Carmichael, G.R., (2000). The growing contribution of sulfur emissions from ships in Asian Waters, 1988-1995. Atmospheric Environment, 34:4425-4439.

[10] Kesgin, U. and Vardar, N., (2001). A study on exhaust gas emissions from ships in Turkish Straits. Atmospheric Environment, 35:1863-1870. 
[11] Deniz, C. and Durmusoglu, Y., (2008). Estimating shipping emissions in the region of the Sea of Marmara. Science of the Total Environment, 390:255-261.

[12] Deniz, C. and Kılıç, A., (2010). Estimation and assessment of shipping emissions in the region of Ambarlı Port, Turkey. Environmental Progress \& Sustainable Energy, 29(1):107-115.

[13] Moreno-Gutiérrez, J., Durán-Grados, V., Uriondo, Z., Ángel-Llamas, J., (2012). Emission-factor uncertainties in maritime transport in the Strait of Gibraltar, Spain. Atmospheric Measurement Techniques, 5:59535991.

[14] Nunes, R.A.O., Alvim-Ferraz, M.C.M., Martins, F.G., Sousa, S.I.V., (2017). Assessment of shipping on four ports of Portugal. Environmental Pollution, 231:1370-1379.

[15] Styhre, L., Winnes, H., Black, J., Lee, J., Le-Griffin, H., (2017). Greenhouse gas emissions from ships in portsCase studies in four continents. Transportation Research Part D: Transport and Environment, 54:212224.

[16] IMO, (2000). Study of Greenhouse Gas Emissions from Ships, Final Report to the International Maritime Organization, Roar Frode Henningsen, Norwegian Marine Technology Research Institute-MARINTEK, Trondheim, Norway.

[17] IMO, (2009). Second IMO GHG Study, International Maritime Organization (IMO), London, UK, April 2009.

[18] Jalkanen, J.P., Johansson, L., Kukkonen, J., Brink, A., Kalli, J., Stipa, T., (2012). Extension of an assessment model of ship traffic exhaust emissions for particulate matter and carbon monoxide. Atmospheric Chemistry \& Physics, 12:2641-2659.
[19] Bal Beşikçi, E., Arslan, O., Turan, O., Ölçer, A.İ., (2016). An artificial neural network based decision support system for energy efficient ship operations. Computers \& Operations Research, 66:393-401.

[20] Bilgili, L. and Çelebi, U.B., (2018). Developing a new green ship approach for flue gas emission estimation of bulk carriers. Measurement, 120:121-127.

[21] Bilgili, L. (2018a). Estimation of Operational Gaseous Emissions in Ship Life Cycle with Machine Learning Method, Ph.D. Thesis in Yildiz Technical University, Istanbul (in Turkish).

[22] Richter, A., Eyring, V., Burrows, J.P., Bovensmann, H., Lauer, A., Sierk, B., Crutzen, P.J., (2004). Satellite measurements of $\mathrm{NO2}$ from international shipping emissions. Geophysical Research Letters, 31, L23110.

[23] De Wildt, M.R., Eskes, H., Boersma, K.F., (2012). The global economic cycle and satellite-derived NO2 trends over shipping lanes. Geophysical Research Letters, 39, L01802.

[24] Johansson, L., Jalkanen,J.P., Kukkonen, J., (2017). Global assessment of shipping emissions in 2015 on a high spatial and temporal resolution. Atmospheric Environment, 167:403415.

[25] USEPA, (2010). Technical Support Document, Social Cost of Carbon for Regulatory Impact Analysis, Interagency Working Group on SCC, US Government.

[26] Maragkogianni, A. and Papaefthimiou, S., (2015). Evaluating the social cost of cruise ships air emissions in major ports of Greece. Transportation Research Part D: Transport and Environment, 36:10-17. 
[27] McArthur, D.P. and Osland, L., (2013). Ships in a city harbour: An economic valuation of atmospheric emissions. Transportation Research Part D: Transport and Environment, 21:4752.

[28] Song, S., (2014). Ship emissions inventory, social cost and ecoefficiency in Shangai Yangshan Port. Atmospheric Environment, 82:288297.

[29] Dragović, B., Tzannatos, E., Tselentis, V., Meštrović, R., Škurić, M., (2015). Ship emissions and their externalities in cruise ports. Transportation Research Part D: Transport and Environment, 61(B):289-300.

[30] Tzannatos, E., (2010a). Ship emissions and their externalities for Greece. Atmospheric Environment, 44:2194-2202.

[31] Gallagher, K.P., (2005). International trade and air pollution: Estimating the economic costs of air emissions from waterborne commerce vessels in the United States. Journal of Environmental Management, 77,:99103.

[32] Kalli, J. and Tapaninen, U., (2008). Externalities of Shipping in the Gulf of Finland until 2015, University of Turku, ISBN: 978-951-29-3779-0, ISSN: 1456-1816.

[33] Tzannatos, E., (2010b). Ship emissions and their externalities for the Port of Piraeus-Greece. Atmospheric Environment, 44:400407.

[34] Maffii, S., Molocchi, A., Chiffi, C., (2007). External Costs of Maritime Transport.

[35] Eyring, V., Köhler, H.W., Lauer, A., Lemper, B., (2005). Emissions from international shipping: 2. Impact of future technologies on scenarios until 2050. Journal of Geophysical Research, 110, D17306.
[36] Bilgili, L., (2018b). A comprehensive review of current legislations and regulations on ship emissions and some comments, 2nd International Symposium on Multidisciplinary Studies and Innovative Technologies, Proceedings, 19-21 October, Ankara, Turkey.

[37] Schembari, C., Cavalli, F., Cuccia, E., Hjorth, J., Calzolai, G., Pérez, N., Pey, J., Prati, P., Raes, F., (2012). Impact of a European directive on ship emissions on air quality in Mediterranen Harbours. Atmospheric Environment, 61:661-669.

[38] Luo, M., (2013). Emission reduction in international shipping-The hidden side effects. Maritime Policy and Management, 40(7), 694-708.

[39] Lindstad, H., Eskeland, G.S., Psaraftis, H., Sandaas, I., Strømann, A.H., (2015). Maritime shipping and emissions: A three-layered, damage-based approach. Ocean Enginerring, 110:94-101.

[40] Trozzi, C., (2010). Emission estimate methodology for maritime navigation, 19th International Emission Inventory Conference Proceedings, 27-30 September, San Antonio, USA.

[41] Moldanová, J., Fridell, E., Petzold, A., Jalkanen, J.P., Samaras, Z., (2010). Emission Factors for Shipping-Final Data for Use in Transphorm Emission Inventories, Transport Related Air Pollution and Health ImpactsIntegrated Methodologies for Assessing Particulate Matter.

[42] https: / / www.world scale. co.uk /BookPage/ BunkerPrice ? s e l e c t e d Y e a $\mathrm{r}=2016$ 2016\&embed=true (Accessed in 24.06.2019)

[43] Matthias, V., Bewersdorff, I., Aulinger, A., Quante, M., (2010). The contribution of ship emissions to air pollution in the North Sea Regions. Environmental Pollution, 158:2241-2250. 
[44] Alföldy, B., Lööv, J.B., Lagler, F., Mellqvist, J., Berg, N., Beecken, J., Weststrate, H., Duyzer, J., Bencs, L., Horemans, B., Cavalli, F., Putaud, J.P., Janssens-Maenhout, G., Csordás, A.P., Van Grieken, R., Borowiak, A., Hjorth, J., (2013). Measurements of air pollution emission factors for marine transportation in SECA. Atmospheric Measurement Techniques, 6:17771791.

[45] Gronlund C.J., Humbert S., Shaked S., O'Neill M.S., Jolliet O., (2015). Characterizing the burden of disease of particulate matter for life cycle impact assessment. Air Quality, Atmosphere \& Health, 8:29-46.

[46] Devleesschauwer B., Havelaar A.H., Noordhout C.M., Haagsma J.A., Praet N., Dorny P., Duchateau L., Torgerson P.R., Oyen H., Speybroeck N., (2014). Calculating disability-adjusted life years to quantify burden of disease. International Journal of Public Health, 59(3):565-569.

[47] Humbert S., Schryver A.D., Bengoa X., Margni M., Jolliet O., (2012). IMPACT 2002+: User Guide. Draft for version Q2.21 (version adapted by Quantis). 